Rafał Makała

Uniwersytet Techniczny w Berlinie

ORCID: 0000-0001-8083-4766

\title{
Nawiązania do tradycji nowożytnej w ceglanej architekturze wczesnomodernistycznej północnych Niemiec
}

DOI: https://doi.org/10.26881/porta.2018.17.04

Mimo ponownego zainteresowania historii sztuki modernizmem, widocznego od ponad dwóch dekad, definiowanie architektury modernistycznej, a zwłaszcza jej początków, jest do dziś przedmiotem dyskusji historycznoartystycznej ${ }^{1}$. Wykształcony w łonie niemieckiej historii sztuki tradycyjny schemat każe za jej początek uznawać 1918 r., co w dużej mierze podyktowane jest kontekstem historycznym - klęską Niemiec w pierwszej wojnie światowej i upadkiem cesarstwa Hohenzollernów. Zjawiska artystyczne o modernistycznych cechach postrzegane są w tym kontekście jako swego rodzaju preludium, określane w niemieckiej literaturze naukowej jako „architektura reformy” (Reformarchitektur), przygotowująca grunt pod właściwą rewolucję w sztuce, związaną z koncepcjami „nowego budowania” (Neues Bauen) i Bauhausu². Podtrzymuje to oczywiście jeden z mitów założycielskich Niemiec po drugiej wojnie światowej, w myśl którego awangarda nie miała nic wspólnego z ruchami narodowymi sprzed $1945 \mathrm{r}$.

1 Niniejszy artykuł powstał na podstawie mojej publikacji książkowej, zob. Rafał Makała, Między prowincją a metropolią. Architektura Szczecina w latach 1891-1918, Szczecin 2011, oraz późniejszych badań, prowadzonych w latach 2016-2018 w czasie pracy na stanowisku profesora historii sztuki środkowoeuropejskiej na Uniwersytecie Technicznym w Berlinie. Fundatorowi profesury, Pełnomocnikowi Rządu Federalnego RFN ds. Kultury i Mediów (Beauftragte der Bundesregierung für Kultur und Medien), chciałbym w tym miejscu wyrazić moją wdzięczność za sfinansowanie badań. O modernistycznej architekturze ceglanej w kontekście oeuvre Fritza Högera pisała m.in. Claudia Turtenwald w znakomitej dysertacji poświęconej temu architektowi, zob. Claudia Turtenwald-Quiring, Fritz Höger (1877-1949). Architekt zwischen Stein und Stahl, Glas und Beton, Münster 2004, https:// www.researchgate.net/publication/35419479_Fritz_Hoger_1877-1949_Architektur_zwischen_Stein_ und_Stahl_Glas_und_Beton [dostęp: 12.06.2018].

2 Na temat Neues Bauen i Bauhausu zob. Ursula Muscheler, Das rote Bauhaus. Eine Geschichte von Hoffnung und Scheitern, Berlin 2016; Anja Baumhoff, Bauhaus [w:] Deutsche Erinnerungsorte. Studien zur historischen Philosophie von Pierre Nora, red. Hagen Schulze, Etienne François, München 2001, s. 584-600; Aber wir sind! Wir wollen! Und wir schaffen! Von der Großherzoglichen Kunstschule zur Bauhaus-Universität. 1860-2010, Bd. 1 (1860-1945), hrsg. Frank Simon-Ritz, Klaus-Jürgen Winkler, Gerd Zimmermann, Weimar 2010; Michael Siebenbrodt, Lutz Schöbe, Bauhaus 1919-1933, New York 2009; Ulrike Müller, Bauhaus-Frauen: Meisterinnen in Kunst, Handwerk und Design. Elisabeth Sandmann, München 2009; Magdalena Droste, Bauhaus 1919-1933. Reform und Avantgarde, Köln 2006. 
W konsekwencji jednak poza obszarem tak rozumianego modernizmu pozostaje zarówno szereg dzieł i projektów modernistycznych, jak i interesujących zjawisk, do których należy silny nurt tradycjonalistyczny określany jako „konserwatywny modernizm" (Konservative Moderne) ${ }^{3}$. Jednym z jego przejawów było odwoływanie się do tradycji budownictwa ceglanego w północnych Niemczech. Apogeum tego nurtu przypadło na lata dwudzieste i trzydzieste XX w. i związane było przede wszystkim z działalnością Fritza Schumachera i Fritza Högera w Hamburgu i Bremie. Jednak geneza tej architektury sięga pierwszej dekady XX w. i wiąże się z próbami kształtowania północnoniemieckiego patriotyzmu przekraczającego granice historycznych krajów i krain. W ten sposób tworzono - a raczej usiłowano tworzyć - nową wspólnotę w obrębie granic zbudowanej przez Ottona von Bismarcka w 1871 r. nowej Rzeszy ${ }^{4}$, odwołującą się przede wszystkim do mitu Hanzy jako prefiguracji morskiej potęgi wilhelmińskich Niemiec. Oczywiście w ostatniej ćwierci XIX i pierwszych latach XX w. posługiwano się przede wszystkimi rozmaitymi formułami dziewiętnastowiecznego historyzmu ${ }^{5}$, przez co północnoniemiecka architektura ceglana tego okresu kojarzy się przede wszystkim $\mathrm{z}$ neogotykiem (w wersji rozpropagowanej przez szkołę hanowerską w trzeciej ćwierci XIX w. bądź w postaci tzw. gotyku marchijskiego, obecnego w kręgu berlińskim od lat osiemdziesiątych XIX w. do końca pierwszej dekady XX w.), a także $\mathrm{z}$ formami tzw. niemieckiego renesansu. Obie te konwencje dziewiętnastowiecznego historyzmu były przez reformatorów architektury mocno krytykowane, a projekty powstające w kręgu twórców wczesnego modernizmu programowo - wręcz manifestacyjnie - dystansowały się od nich ${ }^{6}$. Tym niemniej idee reformy architektury łączyło z ceglanym historyzmem więcej, niżby mogło się wydawać, przede wszystkim wspomniana wyżej patriotyczno-regionalistyczna motywacja. Zarówno u początków ceglanego neogotyku, jak i u źródeł tzw. architektury reformy (Reformarchirektur) leżała bowiem chęć stworzenia specyficznej formuły architektonicznej, z jednej strony intencjonalnie wyrażającej „północnoniemieckiego ducha” (a w rzeczywistości służącej ewokowaniu poczucia wspólnoty północnej części wilhelmińskich Niemiec), z drugiej zaś oddającej rozkwit gospodarczy tego obszaru w drugiej połowie XIX w. i jego modernizacyjny awans w Niemczech oraz w Europie, wynikający

\footnotetext{
3 Termin ten pojawił się na początku lat dziewięćdziesiątych XX w., zob. Romana Schneider, Vittorio Magnago Lampugnani, Architektur in Deutschland 1900-1950, Stuttgart 1994. Zob. także: Martin Ebert, Heinrich Tessenow. Architekt zwischen Tradition und Moderne, Weimar 2006; Beate Störtkuhl, Liegnitz - die andere Moderne. Architektur der 1920er Jahre, München 2007 (Schriften des Bundesinstituts für Kultur und Geschichte der Deutschen im östlichen Europa, Bd. 32).

4 Na temat procesu tworzenia bismarckowskiej Rzeszy zob. Thomas Nipperdey, Deutsche Geschichte 1866-1918, Bd. 1, Arbeitswelt und Bürgergeist, München 1994, s. 331-343, 749-789; Bd. 2, Machtstaat vor der Demokratie, München 1994, s. 12-84.

5 Szerzej na temat definiowania historyzmu zob. Makała, Między prowincją a metropoliq..., s. 11-25; tamże dalsza literatura przedmiotu.

6 Julius Posener, Berlin auf dem Wege zu einer neuen Architektur. Das Zeitalter Wilhelms II, München 1979, s. 8.
}

Nawiąania do tradycji... 
Rafat $\mathrm{z}$ dynamicznej industrializacji na przełomie wieków. W wielu miastach portoMakała wych ówczesnych Niemiec proces ten związany był z polityką zbrojeń morskich, które zapewniały stoczniom i kooperującemu $\mathrm{z}$ nimi przemysłowi stały impuls finansowy ${ }^{7}$. Dzięki temu przełom XIX i XX w. stał się w północnych Niemczech okresem koniunktury budowlanej.

Eksperymenty z ceglaną architekturą neogotycką prowadzono już od początku XIX w. (czego przykładem jest nowy ratusz w Kołobrzegu, odbudowany w latach 1824-1831 według projektu Carla Friedricha Schinkla po zniszczeniach wojen napoleońskich ${ }^{8}$ ). Rozkwit formuły neogotyku ceglanego nastąpił w drugiej połowie stulecia, apogeum osiągając w ostatniej ćwierci XIX i pierwszych latach XX w. Odwoływano się w tej formule przede wszystkim do budownictwa z obszaru państwa zakonu krzyżackiego, do architektury miast hanzeatyckich (przede wszystkim Lubeki), a także - zwłaszcza około 1900 r. - do wspomnianego "marchijskiego” gotyku. Ten ostatni był w istocie kompilacją form późnośredniowiecznej architektury Pomorza Zachodniego, Marchii Brandenburskiej i Nowej Marchii, a także Meklemburgii ${ }^{9}$. Popularność ceglanego neogotyku na północy Niemiec wiązała się ze wspomnianą już specyficzną sytuacją tej części kraju budującej swoją tożsamość w obrębie nowej Rzeszy - jak wspomniałem powyżej - w oparciu o mit Hanzy jako pangermańskiej, narodowej organizacji antycypującej zjednoczenie Niemiec ${ }^{10}$. Poszukiwanie tożsamości spajającej ten historycznie mocno zróżnicowany region doprowadziło do dominacji ceglanego neogotyku w architekturze w budowlach kultowych i użyteczności publicznej ${ }^{11}$. Przyczyniła się też do tego lansowana przez ministra Heinricha von Stephana idea wznoszenia w całej Rzeszy budynków pocztowych posługujących się językiem formalnym ceglanego neogotyku ${ }^{12}$. Niemal równocześnie zaczęto się interesować tzw. niemieckim renesansem - pod pojęciem tym rozumiano budownictwo XVI i pierwszej połowy XVII w. (o ile nie miało ono wyraźnych jeszcze cech gotyckich bądź już barokowych), występujące

7 Nipperdey, Deutsche Geschichte 1866-1918, Bd. 2..., s. 226-265.

8 Manfred Klinkott, Die Backsteinbaukunst der Berliner Schule von K.F. Schinkel bis zum Ausgang des Jahrhunderts, Berlin 1988, s. 62-64.

9 Stan wiedzy na temat architektury gotyckiej wspominanych regionów był oczywiście daleko mniej zaawansowany niż obecnie. Na temat ceglanego neogotyku zob. Günther Kokkelink, Monika Lemke-Kokkelink, Baukunst in Norddeutschland. Architektur und Kunsthandwerk der Hannoverschen Schule 1850-1900, Hannover 1998. Zob. także: Manfred Klinkott, Die Gestaltung von Backsteinfassaden unter dem Einfluss der politischen Verhältnisse in Preußen vor und nach 1871 [w:] Backsteinarchitektur in Mitteleuropa. Neue Forschungen. Protokollband des Greifswalder Kolloquiums 1998, hrsg. Ernst Badstübner, Uwe Albrecht, Berlin 2000, s. 321-343; idem, Die Backsteinbaukunst... s. 426-430.

10 Jörgen Bracker, Mythos und Nachleben der Hanse [w:] Die Hanse, Lebenswirklichkeit und Mythos, hrsg. C. Hirte, Hamburg 1989, s. 652-679.

11 Kokkelink, Lemke-Kokkelink, Baukunst in Norddeutschland..., s. 14-15.

12 Harold Hammer-Schenk, Kunsttheorie und Kunstgeschichte des. 19. Jahrhunderts in Deutschland, Stuttgart 1985, s. 73-77. Zob. także: Makała, Między prowincja a metropoliq..., s. 143-144. 
na terenach północnych Niemiec i Niderlandów, a także Prus Królewskich, Inflant oraz Danii, w większości ceglane, z kamiennymi dekoracjami i detalami architektonicznymi. Architektura ta, podobnie jak późny gotyk, odbierana była jako swego rodzaju „styl hanzeatycki”, odzwierciedlający specyfikę (postrzeganej w zmitologizowany sposób) Hanzy jako prefiguracji zjednoczenia Niemiec i ich potęgi w handlu morskim ${ }^{13}$. W efekcie w stosunkowo krótkim czasie $\mathrm{w}$ północnoniemieckich miastach zaczęły dominować budowle ceglane nawiązujące do gotyku bądź tzw. niemieckiego renesansu. W tak masowym budownictwie nieuchronna była jednak schematyzacja wzorów, co ostatecznie doprowadziło do trywializacji obu tych konwencji i związanych z nimi znaczeń. Wraz ze zmierzchem formuły tradycyjnego, dziewiętnastowiecznego historyzmu ceglana architektura neogotycka i neorenesansowa została stopniowo zarzucona i zapomniana, a w kręgu zwolenników reformy architektury dominowała w pierwszych latach XX w. estetyka neoklasycyzmu bądź też ludowości. Jednak sama idea posługiwania się cegłą i terakotowymi dekoracjami jako materiałami o patriotyczno-regionalnych konotacjach została podjęta w kręgu twórców wczesnego modernizmu związanych z obszarem północnoniemieckim.

Idea „reformy architektury” pojawiająca się w Niemczech od pierwszych lat $\mathrm{XX}$ w. pod wpływem wzorów brytyjskich wiązała się m.in. z próbą odejścia od wspomnianych praktyk historyzmu końca XIX w., w tym przede wszystkim od dosłownego odwzorowywania elementów architektury dawnej na rzecz funkcjonalności rozwiązań i redukcji dekoracji. Nie oznaczało to jednak rezygnacji $\mathrm{z}$ chęci nadania architekturze cech narodowych ${ }^{14}$. Architektura wczesnomodernistyczna nadal odwoływała się do sztuki przeszłości, a dialog z tradycją stanowił jej zasadniczy element. Zmianie uległy jednak sposób odwoływania się do przeszłości - z nielicznymi tylko cytatami ze sztuki dawnej, przy znacznym uproszczeniu form historycznych stylów - oraz historyczny punkt odniesienia. Było to uwarunkowane wspomnianymi już patriotycznymi i regionalistycznymi motywacjami. Wbrew wykształconej w połowie XX w. historycznoartystycznej tradycji pisania o awangardzie moderniści kierowali się często motywami patriotycznymi czy wręcz nacjonalistycznymi. Ruchy demokratyczne w wilhelmińskich Niemczech, stanowiące zaplecze prób reformy architektury, miały bowiem zdecydowanie narodowy charakter, co wiązało się m.in. ze sformułowaną w XIX w. ideą nowoczesnego, narodowego państwa niemieckiego, wykształconą w oparciu o niechęć do krajów uważanych za wrogie (zwłaszcza Francji, ale

13 Szerzej na ten temat zob. Rafał Makała. „Neorenesans pótnocny” jako niemiecki styl narodowy na przełomie XIX i XX w. [w:] Recepcja renesansu w XIX i XX wieku. Materiały Sesji Stowarzyszenia Historyków Sztuki, Łódź, listopad 2002, red. Małgorzata Wróblewska-Markiewicz, Łódź 2003, s. 307-314, tamże dalsza literatura przedmiotu.

14 Podobny stosunek mieli twórcy reformy do secesji, która w Niemczech była zjawiskiem dość efemerycznym i nie doprowadziła do zasadniczych zmian w pojmowaniu architektury, w większości zastępując tradycyjną, wywodzącą się ze średniowiecznych i nowożytnych wzorów ornamentykę nowymi formami. Szerzej na ten temat zob. Makała, Między prowincją a metropoliq..., s. 11-15.
Nawiąania do tradycji... 
Rafat także Rosji, a w początkach XX w. również Wielkiej Brytanii) i żywiącą się dumą Makała z bismarckowskiego zjednoczenia Niemiec i ich cywilizacyjnego sukcesu około 1900 r. ${ }^{15}$ Mitem założycielskim tego państwa (i formującego się w jego ramach narodu) była oczywiście wygrana w 1870 r. wojna z Francją - „odwiecznym wrogiem" ${ }^{16}$. Zasadniczą przyczyną takiego postrzegania zachodniego sąsiada Niemiec były wydarzenia z okresu wojen napoleońskich, nakładały się one jednak na wcześniejsze doświadczenia. Nie bez znaczenia była też widoczna we Francji XVIII w. pogarda wobec Niemców, a także wcześniejsze upokorzenia i klęski, w tym odebranie Świętemu Cesarstwu Rzymskiemu Narodu Niemieckiego Lotaryngii przez Ludwika XIV. Podbój starej Rzeszy dokonany przez cesarstwo Napoleona (wraz z wcześniejszymi próbami przeszczepienia rewolucji na teren Niemiec, podejmowanymi w czasach I Republiki) postrzegano jako kolejne ataki Francji będącej wrogiem niezależnie od formy ustrojowej. Niemieccy demokraci XIX i początków XX w. uznawali Napoleona za agresora, przeciwko któremu obrócił się gniew niemieckiego narodu ${ }^{17}$. Dlatego też dla wilhelmińskich demokratów „złotym wiekiem”, na którym należało się wzorować, był przede wszystkim przełom XVIII i XIX w. Natomiast kulminacyjnym momentem miało być zwycięstwo nad Napoleonem, które około 1900 r. postrzegano w Niemczech przede wszystkim jako efekt połączonych wysiłków monarchów oraz „ludu” (Volk), mitologizując powstańczy zryw społeczeństwa. Do tego okresu odwoływała się fundamentalna dla rozwoju wczesnego modernizmu w Niemczech książka Paula Mebesa Um 1800 (Około 1800). Wydana w 1908 r., przedstawiała zdjęcia obiektów uznawanych za oddające ducha niemieckiego ludu. Choć Mebes starał się przywoływać w swojej książce przede wszystkim dzieła z ostatniej ćwierci XVIII i pierwszych trzech dekad XIX w., to w praktyce architekci sięgali po znacznie szerszą gamę odniesień, nawiązując m.in. do barokowego klasycyzmu i ogólnie do nurtu palladiańskiego w architekturze nowożytnej ${ }^{18}$.

Drugim obszarem inspiracji modernistów była architektura rustykalna, wiejska - używając tego ostatniego określenia, należy jednak pamiętać, że w niedoskonały sposób oddaje ono sens niemieckiego terminu Landbaukunst (a także jego angielskiego odpowiednika country-style). Chodzi bowiem o architekturę tworzoną poza wielkimi centrami sztuki i metropoliami, w obrębie której znajdują się zarówno rzeczywiste budownictwo ludowe ( $\mathrm{tj}$. tworzone przez warstwę chłopską), jak i obiekty lokowane w małych miastach, a także dwory czy folwarki. W wilhelmińskich Niemczech $\mathrm{w}$ tego rodzaju budownictwie widziano

\footnotetext{
15 Nipperdey, Deutsche Geschichte 1866-1918..., Bd. 2, Machtstaat vor der Demokratie, s. 286-289.

16 Deutsche Erinnerungsorte..., s. 391-468.

17 Peter Hutter, Die feinste Barbarei. Das Völkerschlachtdenkmal bei Leipzig. Eine Studie über die "germanische" Kunst des 19. Jahrhunderts, Mainz 1990, s. 15-18; Otto W. Johnston, Der deutsche Nationalmythos. Ursprung eines politischen Programms, Stuttgart 1990, s. 49-76.

18 Posener, Berlin auf dem Wege..., s. 188-196, 369-381.
} 
wizualizację cech mieszczańskich, będących zarazem przymiotami Niemców jako (nowego) narodu - wśród tych cech lokując też patriotyzm, waleczność, upór czy bezinteresowność ${ }^{19}$. W tego rodzaju budownictwie dopatrywano się też cech, które przez modernistów cenione były z powodów estetycznych i stanowiły wspólne dobro europejskich ruchów reformy sztuki - m.in. używania solidnych materiałów regionalnego pochodzenia, redukcji dekoracji czy swobodnego stosunku do form dekoracyjnych. Stąd również wzięło się zainteresowanie wczesnego modernizmu cegłą i terakotą jako tworzywem, choć oczywiście ważną, jeśli nie decydującą rolę odegrało tu dowartościowanie budownictwa industrialnego. W architekturze wczesnego modernizmu pierwszych dwóch dekad XX w. pojawiały się ceglane budowle - jednak kojarzy się je przede wszystkim $\mathrm{z}$ industrialną estetyką budynków Petera Behrensa (hala produkcji turbin AEG przy Huttenstrasse na Moabicie w Berlinie, 1908-1909), Hansa Poelziga (fabryka chemiczna Moritz Milch \& Co. w Luboniu koło Poznania, 1911-1912) czy Waltera Gropiusa (budynek fabryki obuwniczej Fagus w Alfeld, 1911-1914) ${ }^{20}$. Wraz $\mathrm{z}$ pojawieniem się $\mathrm{w}$ architekturze modernistycznej w obszarze północnoniemieckim obiektów inicjujących nurt technicystyczny, zaczęły powstawać budowle świadomie nawiązujące do tradycji nowożytnej i konsekwentnie posługujące się ceglanym i terakotowym materiałem. Miało to bezpośredni związek z nurtem „ochrony rodzimości” (Heimatschutzbewegung), zainicjowanym przez Paula Schulze-Naumburga. Jednak zjawisko to zyskało szerszy zasięg i większe znaczenie niż sam ruch „ochrony rodzimości”, zwłaszcza w obszarze północnoniemieckim, gdzie nawiązania do nowożytnej architektury w budownictwie ceglanym były dość częste. Widoczne jest to w twórczości najważniejszych architektów północnoniemieckiego modernizmu, Fritza Högera, Fritza Schumachera czy Bruno Möhringa, a także w dziełach mniej znanych, choć z pewnością interesujących twórców, takich jak Johann Garleff, Erich Blunck czy Eugen Prinz. Zainteresowanie północnoniemieckich przedstawicieli wczesnego modernizmu budownictwem ceglanym wiąże się przede wszystkim z twórczością dwóch pierwszych architektów - Högera i Schumachera. Stanowi ono jednak tylko element szerszego procesu, który z ogromną dynamiką przebiegał w północnych Niemczech od pierwszych lat XX w. Co interesujące, proces ów był równie intensywny w wielkich ośrodkach artystycznych (Hamburgu i Bremie) i w miastach o mniejszym znaczeniu, szukających swojej identyfikacji lub usiłujących ją odtworzyć, jak to miało miejsce w Kilonii, Lubece czy Szczecinie.

Zmianę w podejściu do problemu nawiązywania do regionalnych cech architektury dawnej we współczesnym budownictwie zwiastowały dyskusje toczone przy okazji tzw. konkursów fasadowych (Fassadenwettbewerb), rozpisanych

19 Ibidem, s. 212-223.

20 Znakomitej - do dziś aktualnej - charakterystyki stosunku modernistów do budownictwa industrialnego dokonał Julius Posener, zob. Posener, Berlin auf dem Wege... s. 387-401. 
Rafał na przełomie XIX i XX w. m.in. w Lubece (1901) i Gdańsku (1902)21. ZadaMakała nie, które postawiono przed uczestnikami konkursu w obu wspomnianych przypadkach, obejmowało stworzenie wzorów fasad odpowiadających charakterowi miast, ich historycznej zabudowie. Przygotowanie katalogu wzorów, dostępnych zarówno dla twórców, jak i zleceniodawców, miało powstrzymać proces wypierania form rodzimych przez standardowe, całkowicie oderwane od regionalnej tradycji „produkty” kosmopolitycznych architektów. Jednak tradycyjny sposób myślenia o tworzeniu regionalistycznej, północnoniemieckiej architektury widoczny był niemal we wszystkich projektach konkursowych, cytujących obficie najbardziej znane budowle zabytkowe Lubeki i Gdańska. W obu wypadkach autorami większości nagrodzonych bądź wyróżnionych prac byli twórcy wywodzący się spoza miejscowego środowiska, głównie berlińscy i hamburscy, operujący mocno heterogenicznym, ale za to w niewielkim tylko stopniu specyficznie regionalnym zasobem form ${ }^{22}$.

Choć konkursy fasadowe nie przyniosły spodziewanych rezultatów, to jednak stały się okazją do refleksji nad formami o regionalnej specyfice i zaowocowały powstaniem szeregu interesujących budowli. Wiele z nich można zaliczyć do nurtu późnego historyzmu, charakteryzującego się redukcją i uproszczeniem dekoracji ${ }^{23}$. Pojawiły się jednak także realizacje nowatorskie. Należał do nich m.in. obszerny dom wzniesiony w Lubece (w wyniku rozpisanego w 1905 r. konkursu) po wschodniej stronie Bramy Zamkowej (Burgtor). Autorem projektu był jeden $\mathrm{z}$ najbardziej konsekwentnych zwolenników reformy architektury Erich Blunck, współpracujący przy tym zadaniu z mniej znanym architektem berlińskim, Otto Eggelingiem ${ }^{24}$ (il. 1). Zadanie, przed którym stanęli

21 Na temat konkursów na fasady w wilhelmińskich Niemczech pisał obszernie Michael Brix, Nürnberg und Lübeck im 19. Jahrhundet. München 1981, s. 283-293. Konkursy w Lubece i Gdańsku zestawiła Zofia Maciakowska,Gdański konkurs architektoniczny z roku 1902 [w:] Kamienica w krajach Europy Pólnocnej, red. Maria Sołtysik, Gdańsk 2004, s. 327-337. Zob także: Ewa Barylewska-Szymańska, Gdańskie i lubeckie stowarzyszenia na rzecz ochrony zabytków w XIX i poczatkach XX wieku [w:] Studia z historii sztuki i kultury Gdańska i Europy Pólnocnej. Prace poświęcone pamięci Doktor Katarzyny Cieślak, red. Jacek Friedrich, Edmund Kizik, Gdańsk 2003, s. 401-402.

22 Znakomitym przykładem jest fakt nagrodzenia w gdańskim konkursie pracy wrocławskiego architekta Friedricha (?) Dobermanna, która poza przedprożem nie prezentowała żadnych elementów specyficznych dla historycznej architektury Gdańska, zob. Jacek Friedrich, Walka obrazów. Przedstawienia wobec idei w Wolnym Mieście Gdańsku. Gdańsk 2018, s. 62; tamże dalsza literatura przedmiotu.

23 Przykładem jest m.in. gmach dawnej Biblioteki Pruskiej (ob. Biblioteka Państwowa, Staatsbibliothek) przy Unter den Linden w Berlinie, wybudowany według projektu Ernsta von Ihnego w latach 1902-1912. W Lubece nurt ten był widoczny w realizacjach Johanna Balzera (m.in. Szkoła Ernestyny, Ernestinenschule przy Kleine Burgstrasse, wzniesiona w latach 1903-1904 w miejscu trzech barokowych kamienic tzw. Kurii Behrnstorffa).

24 Hans-Günther Andresen, Bauen in Backstein. Schleswig-Holsteinische Heimatschutz-Architektur zwischen Tradition und Reform, Heide in Holstein 1989, s. 46-47. Podział zadań między architektami nie jest jasny, przyjmuje się jednak, że Blunck zajmował się formą architektoniczną budynku, zaś Eggeling jego strukturą techniczną. 


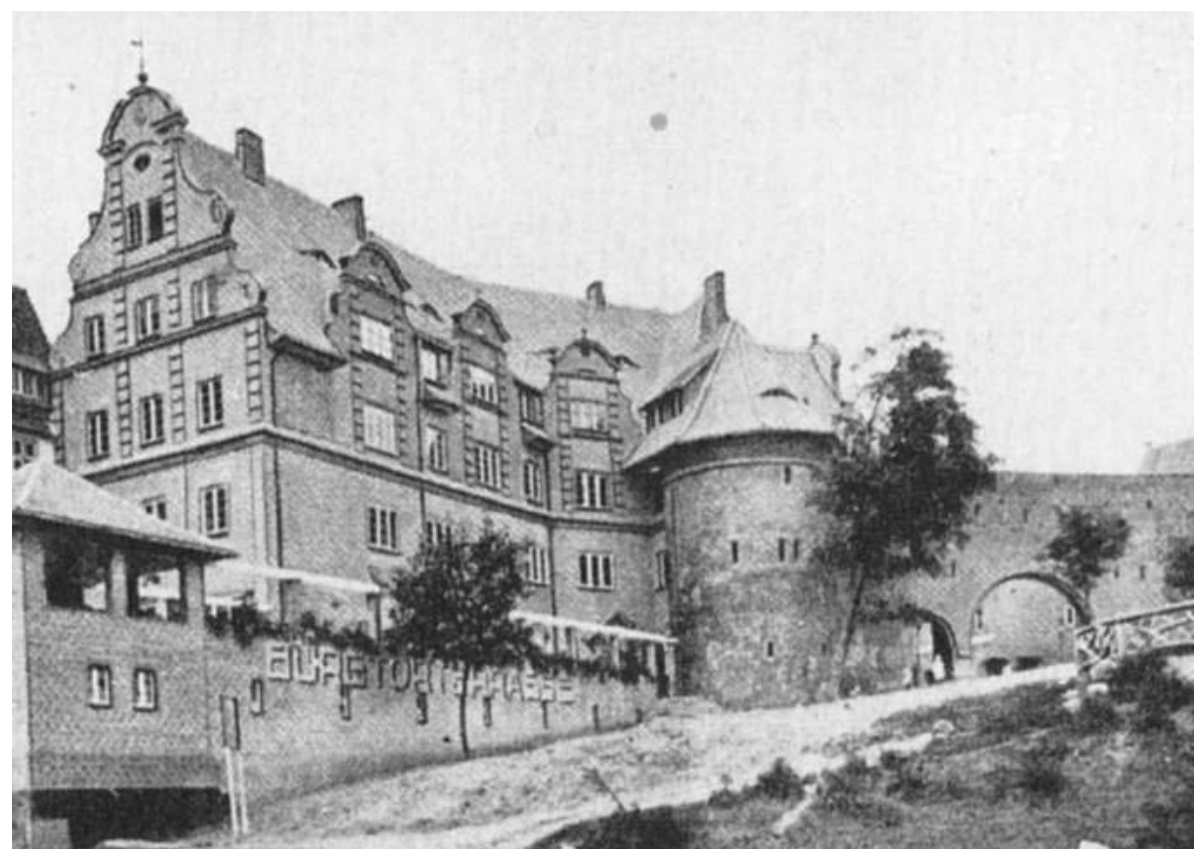

Nawiązania do tradycji...

Il. 1. Erich Blunck, Otto Egeling, dom mieszkalny przy Burgtor w Lubece, 1905, stan pierwotny, repr. za: Hans-Günther Andersen, Bauen in Bockstein..., Heide in Holstein 1999

architekci, miało silne implikacje konserwatorskie (w rozumieniu ochrony zabytków), chodziło bowiem o zaprojektowanie budynku mieszkalnego stanowiącego przedłużenie murów obronnych, zachowanych przy okazałej, średniowiecznej bramie miejskiej. Blunck nie sięgnął jednak po formy ceglanego neogotyku, które w Lubece wydawały się niemal naturalne. Stworzył natomiast obiekt będący pastiszem barokowej kamienicy, nawiązując w ten sposób do historii miasta. W istocie bowiem domy mieszkalne budowane w oparciu o średniowieczne umocnienia powstawały w Lubece dopiero od schyłku XVI, a głównie w XVII i XVIII w., kiedy wzniesiono nowe, bastionowe umocnienia miasta ${ }^{25}$. Szczytowa elewacja budynku przypominała barokową fasadę kamienicy, była jednak dość sumarycznie opracowana, a przy tym wyprowadzona w całości z cegły, uzupełnionej terakotowymi elementami dekoracyjnymi. Boczne elewacje - zwłaszcza północną - opracowano znacznie bardziej sumarycznie. W dolnej partii nawiązują one do muru obronnego, z którym budynek łączy się płynnie (przy czym w obręb domu włączono odbudowaną i nakrytą nowym dachem basztę). W dolnej partii północna elewacja pozostała całkowicie nierozczłonkowana, natomiast $\mathrm{w}$ górnej przecięto ją boniowanymi na narożach wystawkami z segmentowymi naczółkami, nawiązującymi do lubeckiej

25 Zob. Manfred Finke, Altstadt von Lübeck, Stadtdenkmal der Hansezeit, Kiel 2006 s. $202-203,211$. 
Rafał architektury XVIII w. ${ }^{26} \mathrm{~W}$ efekcie powstało wrażenie, jakby dom w dolnej Makała partii wykorzystywał dawny mur obronny, przepruty tylko oknami. Wspomniane wyżej wystawki Blunck i Eggeling zaprojektowali dopiero od poziomu, na którym na północ od baszty kończył się zachowany mur miejski. Dzięki temu formy architektoniczne domu przy Burgtor przypominały fasady kamienic lubeckich XVIII w., czerpiąc jednak z tradycji barokowej architektury ceglanej północnej Europy (obszaru rozciągającego się od Holandii, przez północne Niemcy, Pomorze Gdańskie, Skandynawię, aż po Inflanty). Surowa ceglana ściana, bez podziałów architektonicznych, $\mathrm{z}$ wtopioną w nią basztą łączyły dom przy Burgtor ze średniowiecznymi murami miejskimi. Nawiązując równocześnie do ceglanej architektury barokowej północnych Niemiec, do regionalnej (lubeckiej) tradycji oraz do kontekstu urbanistycznego i architektonicznego nowego obiektu, dom przy Burgtor został włączony w trzy różne narracje. Było to możliwe przede wszystkim dzięki redukcji, a także wyraźnemu uproszczeniu form architektonicznych wzorowanych na historycznych. Dzięki temu dzieło Bluncka i Eggelinga jest doskonałym przykładem ewoluowania architektury późnego historyzmu w stronę idei tzw. Heimatschutzbewegung.

Obiekty utrzymane w konwencji, której przykładem jest omówiona powyżej lubecka realizacja, powstawały nie tylko przed pierwszą wojną światową, lecz także w okresie międzywojennym ${ }^{27}$. Choć sięgały one do wzorów sztuki dawnej w bezpośredni sposób, tworzyły podstawę pod wykształcenie się nowej formuły odwoływania się do historii w architekturze ceglanej początków XX w., przede wszystkim dzięki redukcji i upraszczaniu form. W efekcie na przełomie pierwszej i drugiej dekady XX w. pojawiło się sporo realizacji wracających do stosowania cegły jako dominującego, a niekiedy jedynego tworzywa elewacji - jednak bez nawiązań do gotyku czy renesansu. Przykładem są budynki kantorów (jak w ówczesnym Hamburgu nazywano biurowce firm związanych z portem) wzniesione przez Högera w latach 1910-1914 ${ }^{28}$. Wszystkie nawiązywały do architektury nowożytnej, jednak Höger stopniowo odchodził w nich od dosłownego cytowania elementów historycznych na rzecz uproszczeń i redukcji form. Pierwszym ze wspomnianych obiektów był wybudowany w latach 1910-1911 Haus Glass (il. 2), którego elewację ukształtowano - w podobny sposób jak w domu przy Burgtor w Lubece - za pomocą elementów zaczerpniętych z tradycji nowożytnej. Jest to narożny budynek z dwoma

26 Ibidem, s. $272-276$.

27 Przykładem trwania tej konwencji jest zespół budynków osiedla inwalidów wojskowych w berlińskiej dzielnicy Frohnau, wybudowany przez Waltera Hagena i Erharda Kallmayera w latach 1937-1939. Zob. Thomas Darenberg, Die Invalidensiedlung in Berlin-Frohnau (1937-1939) als Beispiel für eine militärische Wohnanlage in der Zeit des Nationalsozialismus [w:] Städtische und ländliche Siedlungsarchitektur zwischen 1900 und 1960 in Mecklenburg und Vorpommern sowie anderen Regionen, hrsg. Bernfried Lichtnau, Greifswald 1999, s. 283-298.

28 Informacje na temat omówionych dalej budynków Högera zob. Piergiacomo Bucciarelli, Fritz Höger. Hanseatischer Baumeister 1877-1949, Berlin 1992. 
pseudoryzalitami zwieńczonymi wolutowymi szczytami, przypominającymi fasady osiemnastowiecznych kamienic holenderskich czy budowli Johanna Conrada Schlauna ${ }^{29}$. Ścięty narożnik budynku ozdobiono bogato dekorowanym wykuszem. O ile jednak boczne partie zrealizowane zostały w materiale ceglanym, o tyle wykusz wykonano $\mathrm{z}$ jasnego kamienia, co zbliża dzieło Högera do późnohistorystycznych budowli w duchu "niemieckiego renesansu", takich jak gmach Szkoły Nawigacji w Hamburgu, wzniesiony według projektu Alberta Erbe w latach 1903-1905 ${ }^{30}$. Motyw pseudoryzalitu przypominającego fasadę kamienicy zastosował Höger jeszcze w budynku Caledonii z lat 1912-1914, jednak już wcześniej powstał tzw. Neues Klöpperhaus (1912-1913), w którym nie ma szczytów, a elewacje opięte są kolosalnymi jońskimi pilastrami, między którymi ściana wybrzusza się w sposób znany $\mathrm{z}$ architektury domów towarowych. Najbardziej radykalny w redukcji dekoracji był jednak Rappolthaus

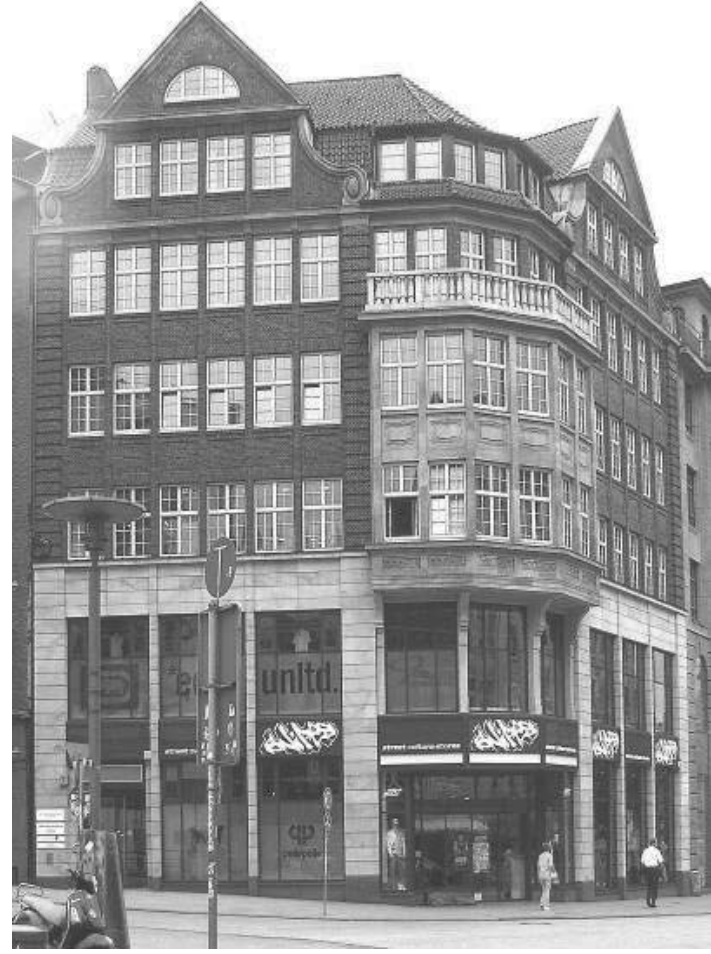

Il. 2. Fritz Höger, biurowiec Haus Glass (tzw. Predigerhaus) w Hamburgu, 1910-1911, stan obecny, Copyright: Staro 1., repr. za: Wikimedia Commons na zasadach CC BY-SA 3.0, https://commons.wikimedia.org/wiki/File:Hhgrellhaus.jpg?uselang=de przy Mönckebergstrasse, wybudowany w 1912 r., z krystaliczną strukturą bryły podzielonej silnymi akcentami horyzontalnymi i z abstrakcyjnymi niemal dekoracjami elewacji.

Nowa formuła ceglanej architektury pojawiła się także w architekturze dworów w północnych Niemczech, zwłaszcza w Szlezwiku-Holsztynie, Księstwie Oldenburskim i we Fryzji. Twórcy tego rodzaju siedzib nawiązywali zwykle do zdefiniowanej przez Mebesa „sztuki około 1800”, jak to uczynił Ernst Prinz w wybudowanym w latach 1910-1911 domu rodziny Buchholz w Bordesholmie koło Eckernförde w Holsztynie. Jest to niewielki, skromnie dekorowany, ceglany, parterowy budynek, który ujmuje z trzech stron niewielki, prostokątny dziedziniec poprzedzony zewnętrznym podwórcem $\mathrm{z}$ trawnikami i podjazdem.

29 Np. zamek myśliwski Clemenswerth w Westfalii (1736-1745) czy Erbdrostenhof w Münster (1753-1757). Zob. Ehrenfried Kluckert, Architektur des Barock in Deutschland, der Schweiz, Österreich und in Osteuropa [w:] Die Kunst des Barock. Architektur - Skulptur - Malerei, hrsg. Rolf Thoman, Köln 1997, s. 190-193.

30 Ralf Lange, Architektur in Hamburg, Hamburg 2008, s. 84-85. 
Rafał Prinz w centrum fasady korpusu zaprojektował trójosiowy pseudoryzalit Makała $\quad \mathrm{z}$ boniowanymi narożnikami i trójkątnym szczytem, natomiast boczne elewacje pozostawił bez dekoracji i podziałów, nawiązując w ten sposób do lokalnego budownictwa folwarcznego i dworskiego XVII-XVIII w. ${ }^{31} \mathrm{~W}$ architekturze tego obiektu widoczny jest niewątpliwie wpływ duńskiego budownictwa willowego. Przykładem może być dom Ernsta Møllera w Kopenhadze, wybudowany przez Carla Haralda Brümmera w latach 1909-191032.

Wspomniany wcześniej Schumacher zainteresował się cegłą jako elementem tworzenia fasady dopiero po przeniesieniu się do Hamburga w 1909 r., a więc w podobnym czasie co Höger. Jeszcze przed wybuchem pierwszej wojny światowej Schumacher zdołał zaprojektować kilka interesujących ceglanych gmachów, posługując się elementami zaczerpniętymi z architektury nowożytnej - m.in. Instytut Medycyny Tropikalnej (1910-1914), obszerny trójskrzydłowy gmach położony na północnym brzegu Łaby ${ }^{33}$ (il. 3).

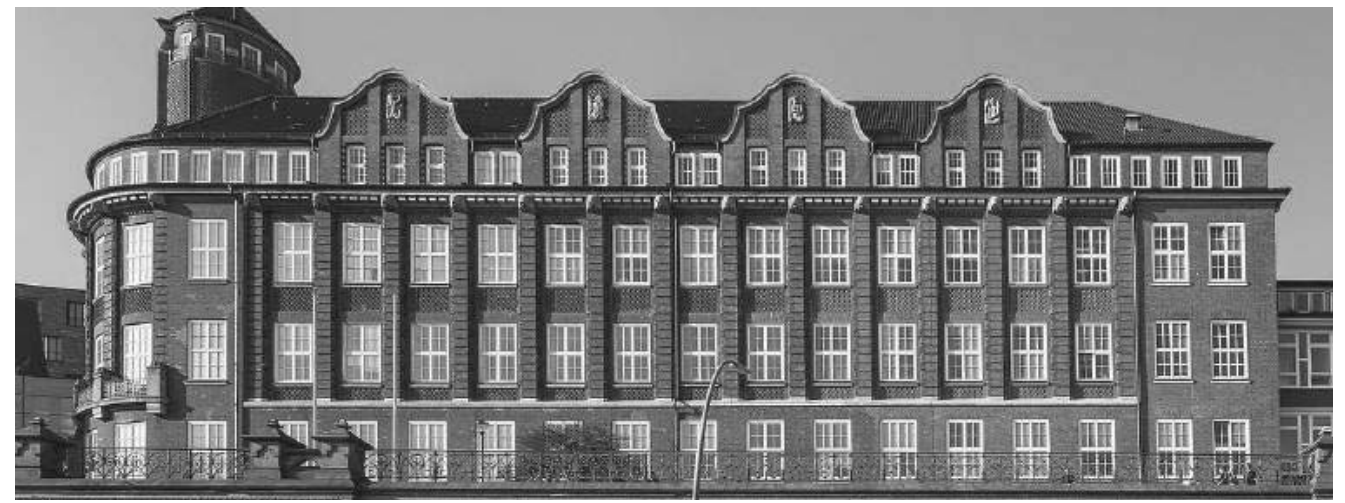

Il. 3. Fritz Schumacher, Instytut Medycyny Tropikalnej w Hamburgu, 1910-1914, stan obecny, Copyright: Ajepbach, repr. za: Wikimedia Commons na zasadach CC BY-SA 3.0.DE, https://commons.wikimedia.org/wiki/ File:Bernhard-Nocht-Stra\%C3\%9Fe_74_(Hamburg-St._Pauli).3.13718.ajb.jpg?uselang=de

Fasadę budynku wykonano z cegły, jednak detale architektoniczne - m.in. jońskie kapitele kolosalnych pilastrów, konsole czy reliefowe płyciny - z kamienia,

31 Na temat założeń dworskich w Szlezwiku-Holsztynie zob. Michael Paarmann, Historische Gutsanlagen in Schelswig-Holstein. Ein ausgeschlagenes Erbe oder Chance für die Zukunft [w:] Schlösser und Herrenhäuser der Ostseeregion. Bausteine einer europäischen Kulturlandschaft, hrsg. Kilian Heck, Sabine Bock, Jana Olschewski, Schwerin 2017, s. 387-400.

32 Był to ceglany budynek o asymetrycznej bryle i elewacjach pozbawionych niemal całkowicie dekoracji, choć jego bryła architektoniczna (w tym zwłaszcza wysokie, spływowe szczyty ryzalitów) nasuwała skojarzenia z pozamiejskim budownictwem XVI w., pozwalając na snucie analogii z wiejskim dworem. Zob. Peter Haiko, Die Architektur des XX. Jahrhunderts. Zeitschrift für moderne Baukunst. Tübingen 1989, s. 225-226.

33 Wszystkie informacje dotyczące dzieł Fritza Schumachera za: Reform der Großstadtkultur - das Lebenswerk Fritz Schumachers (1869-947). Dokumentation zur gleichnamigen Ausstellung 2013 im Kunsthaus Hamburg, hrsg. Dieter Schädel, Jörg Beleites, Hamburg 2013. 
podobnie jak w Klöpperhaus czy w Haus Glass Högera. Podziały architektoniczne i większość detali odwołują się do tradycji nowożytnej, jednak w dziele Schumachera pojawiają się też elementy inspirowane budownictwem średniowiecza, np. wzór z główek cegieł na trzonie wieży. W swoich następnych realizacjach, m.in. gmachu szkoły rzemiosł artystycznych (Kunstgewerbeschule) w hamburskiej dzielnicy Uhlenhorst (1911-1914), komisariacie policji Dawidwache w dzielnicy St. Pauli (1913-1914) czy Muzeum Historii Hamburga (1914-1922) (il. 4), architekt pozostawał wierny tej manierze. Jego poglądy na architekturę ceglaną zaczęły się radykalizować dopiero w czasie pierwszej wojny światowej, gdy - m.in. pod wpływem Friedricha Naumanna (z którym znał się jeszcze z okresu pracy w Lipsku w latach 1896-1901) - zaczął opowiadać się za odejściem od neoklasycyzmu na rzecz szeroko pojętej ludowości w duchu Heimatschutzbewegung 34 .

Dalsza ewolucja architektury ceglanej wczesnego modernizmu w północ-

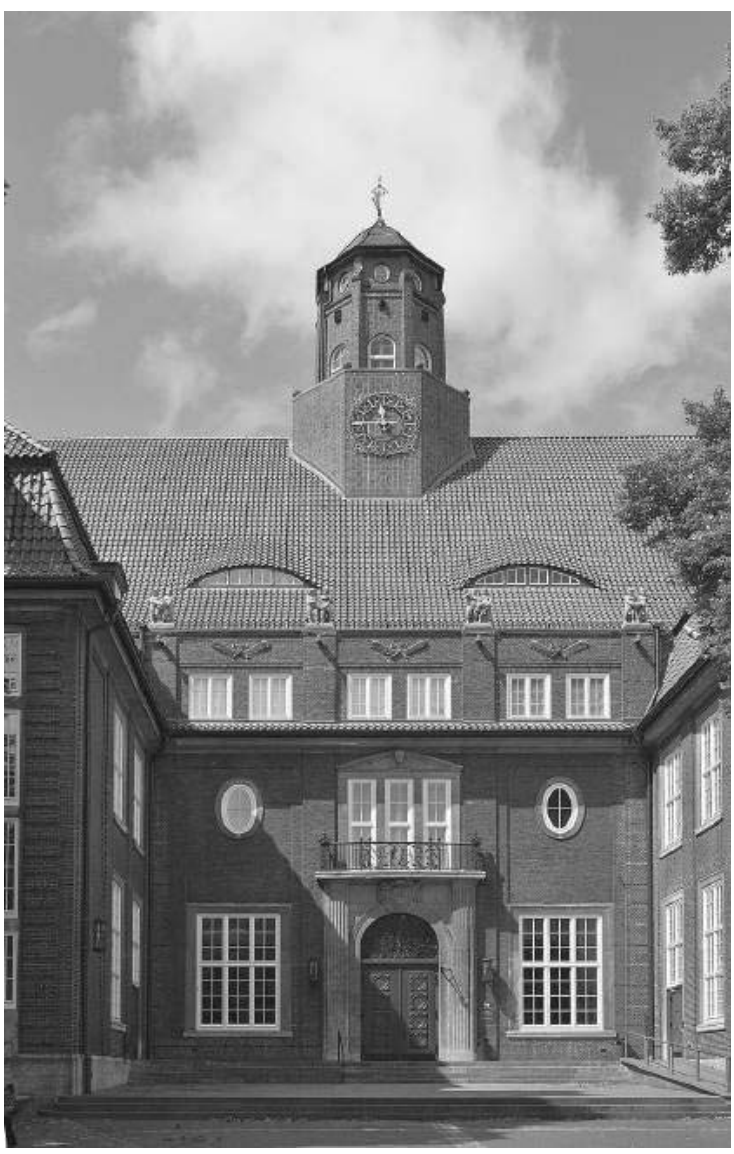

Il. 4. Fritz Schumacher, Muzeum Historii Hamburga, 1914-1922, stan obecny, Copyright: Mbdortmund, repr. za: Wikimedia Commons na zasadach GNU Free Documentation License, version 1.2. nych Niemczech prowadziła w stronę redukcji dekoracji i elementów architektonicznych oraz nadawania im coraz bardziej abstrakcyjnych form i coraz bardziej swobodnego łączenia motywów. Znakomitym przykładem tego rodzaju kompozycji jest budynek szkoły podstawowej

34 Estetykę tę znakomicie ilustruje wypowiedź Fritza Schumachera sformułowana u progu pierwszej wojny światowej: „Es [das Kulturideal] ist ein anderes geworden; in der Epoche der Großstadt und der Maschinen wird es gefärbt von sozialen und wirtschaftlichen Forderungen; Warenhaus, Kleinwohnungsanlage, Volksschule und Fabrik sind nicht mit der aristokratischen Formenwelt der Antike zu lösen, höchstens die rhythmischen Werte ihres abgeklärten Wesens können uns Wegweiser werden. Für die großen sozialen Organisationen unserer Zeit mußten wir den Ausdruck finden. Eine Kunst, die für das Volk schafft, wird unsere nächste Aufgabe ihrem Inhalte nach sein, und das ideale Ziel, das hinter dieser Aufgabe steht, wird sein, nicht nur eine Kunst für das Volk, sondern eine Kunst des Volkes langsam daraus zu entwickeln”. Zob. Fritz Schumacher, Grundlagen der Baukunst, München 1916, s. 64-65. 
(obecnie Brüder-Grimm-Schule) w Kronshagen koło Kilonii, wzniesionej według projektu Johanna Garleffa w latach 1911-1912 (il. 5, 6) ${ }^{35}$. Garleff, który karierę rozpoczynał w latach dziewięćdziesiątych XIX w. od projektów utrzymanych

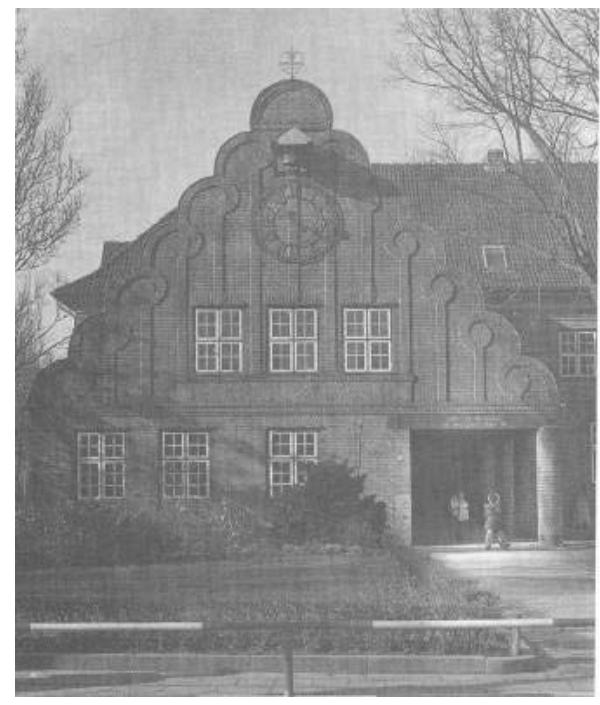

Il. 5. Johann Garleff, szkoła im. Braci Grimm w Kronshagen koło Kilonii, 1911-1912, stan $\mathrm{z}$ lat siedemdziesiątych XX w., HansGünther Andersen, Bauen in Bockstein..., Heide in Holstein 1999

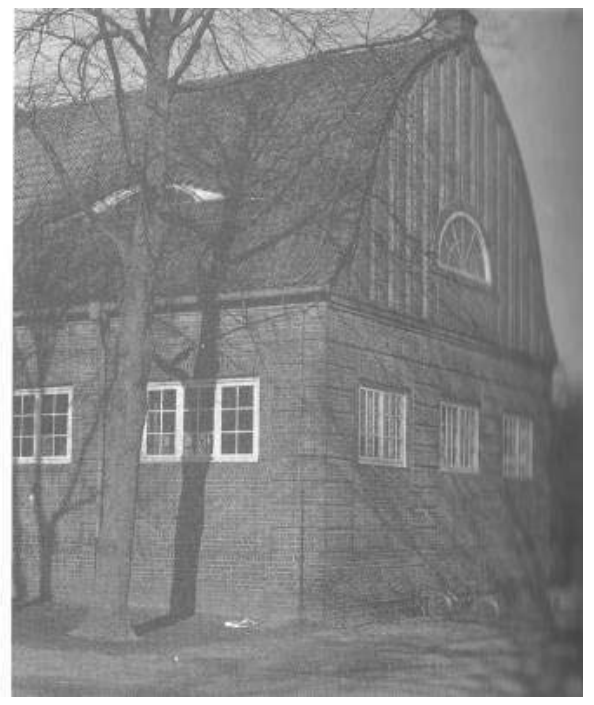

Il. 6. Johann Garleff, szkoła im. Braci Grimm w Kronshagen koło Kilonii, 1911-1912, stan z lat siedemdziesiątych XX w., Hans-Günther Andersen, Bauen in Bockstein..., Heide in Holstein 1999

w duchu szkoły hanowerskiej ${ }^{36}$, sięgnął tu po zupełnie inne wzory. Obszerny budynek wzniesiono konsekwentnie z cegły, z której wykonano też nieliczne dekoracje. Szczególnie interesującym elementem kompozycji fasady jest szczyt ryzalitu mieszczącego wejście. Podzielono go pionowymi pasami, których górne końce przechodzą $\mathrm{w}$ woluty oplatające kolejny pas, tworząc $\mathrm{w}$ ten sposób dynamiczną sylwetkę szczytu. Ściany dłuższych elewacji budynku pozostały nierozczłonkowane, natomiast ściany szczytowe skrzydeł podzielono boniowanymi lizenami, same szczyty dzieląc pionowymi pasami (jednak już bez wolut). Jeszcze bardziej abstrakcyjnie ukształtował Garleff portyk po północnej stronie wspomnianego ryzalitu - tworzy go rząd cylindrycznych słupów, dźwigających uproszczony

35 O ceglanej architekturze początków XX w. w Szlezwiku-Holsztynie pisał obszernie Hans-Günther Andresen - nie wiążąc jej jednak z początkami modernizmu, ale widząc w niej zjawisko z kręgu Heimatschutzarchitektur. Andresen scharakteryzował to zjawisko jako pierwszy. Jego zasługą jest też „odkrycie” oeuvre Johanna Garleffa, w tym także szkoły w Kronshagen jako wybitnego dzieła architektury. Zob. Hans-Günther Andresen, Bauen in Backstein. Schleswig-Holsteinische Heimatschutz-Architektur zwischen Tradition und Reform (Schriften der Schleswig-Holsteinischen Landesbibliothek, herausgegeben von Dieter Lohmeier, Bd. 8), Heide in Holstein 1989, s. 92.

36 Ibidem, s. 25. 
architraw. W efekcie budynek szkoły w Kronshagen odwoływał się wprawdzie do budownictwa folwarcznego Szlezwiku-Holsztynu XVII i XVIII w. - kształtem bryły, ceglanym materiałem elewacji a także schematem ich dekoracji - jednak tylko w ogólny sposób, nie cytując dosłownie historycznych form. Wertykalne dekoracje szczytów nawiązywały bardziej do architektury późnogotyckiej niż nowożytnej. Budynek miał się kojarzyć z miejscową tradycją, ponieważ jednak nie cytował form, które mogłyby zostać jednoznacznie przyporządkowane do konkretnych wzorów regionalnych, był w swojej „północnoniemieckości” znacznie bardziej uniwersalny niż budowle późnego historyzmu.

Na przełomie pierwszej i drugiej dekady XX w. cegłą jako elementem kształtowania zewnętrza budynków, zaczęli się posługiwać twórcy, którzy wcześniej zupełnie nie interesowali się tego rodzaju estetyką. Przykładem tego jest zwrot, który dokonał się w twórczości Bruno Möhringa, wcześniej posługującego się przede wszystkim formami rustykalnymi oraz neoklasycznymi. W $1911 \mathrm{r}$. zaprojektował on w Szczecinie willę rodziny Ossentów - obszerny budynek z centralnym ryzalitem od strony fasady, nakrytym spływowym szczytem (il. 7). W przeciwieństwie do omówionej powyżej realizacji Garleffa Möhring nie ograniczył dekoracji do wzorów układanych z cegieł, lecz zastosował szereg terakotowych elementów dekoracyjnych (m.in. dekoracyjne płyciny ornamentalne nad wejściem), włączając w kompozycję także elementy kamienne (m.in. granitowe słupki dzielące okna wiatrołapu). W efekcie powstała fasada będąca przekładem mebesowskiej estetyki „około 1800” na język ceglanego materiału. Taka

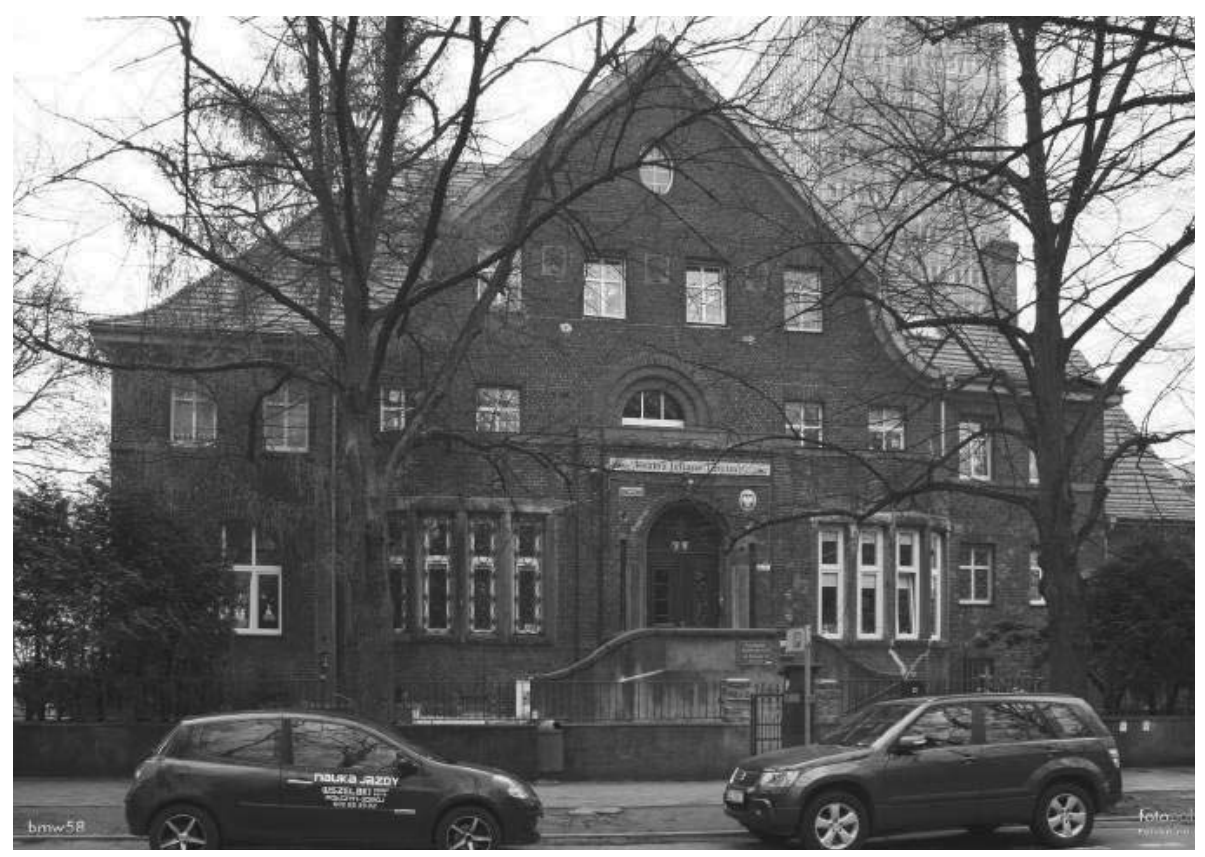

Il. 7. Bruno Möhring, dom rodziny Ossent w Szczecinie, 1911, stan z 2010, fot. Rafał Makała
Nawiąania do tradycji... 
Rafał formuła pozostała najbardziej popularną w świecie wczesnego modernizmu Makała wersją kształtowania ceglanej elewacji architektury ${ }^{37}$.

Powyższy przegląd przykładowych realizacji pozwala dostrzec niezwykłą, nawet w tym okresie gwałtownych przemian w sztuce, dynamikę rozwoju koncepcji ceglanej architektury wczesnego modernizmu w północnych Niemczech. Nurt ten zaczyna być widoczny u schyłku pierwszej dekady XX w., po okresie całkowitego niemal odrzucenia wcześniejszych formuł ceglanej architektury - neogotyku i tzw. niemieckiego renesansu. Ponowne zainteresowanie tym materiałem spowodowane było z jednej strony dowartościowywaniem budownictwa utylitarnego - które w wilhelmińskich północnych Niemczech w przeważającej większości posługiwało się w elewacjach materiałem ceglanym - z drugiej zaś studiami nad architekturą prowincjonalną (Landbaukunst). To drugie zjawisko wiązało się w tej części Niemiec z dążeniem do stworzenia czytelnego „stylu północnoniemieckiego”, mającego stanowić wyróżnik wizualny. W przeciwieństwie do wspominanych wcześniej działań, podejmowanych w XIX w., które doprowadzily do „odkrycia” ceglanego gotyku i architektury renesansu północnoeuropejskiego, zainteresowanie twórców zwróciło się jednak ku formom sztuki końca XVIII i początków XIX w., kreowanej na styl niemieckiego mieszczaństwa, ku „sztuce około 1800”. Stała się ona dzięki temu wizualną formułą narodowych demokratów w wilhelmińskich Niemczech, niosącą modernizacyjne i egalitarystyczne treści. Jednak jej formy, cytowane w przywoływanej tu już wielokrotnie fundamentalnej dla tego ruchu książce Mebesa, należały do instrumentarium późnego baroku oraz oświeceniowego klasycyzmu, w większości nieoperującego cegłą jako materiałem tworzenia fasady. W efekcie architekci byli zmuszeni odwoływać się do nielicznych ceglanych obiektów z XVIII i XIX w. bądź transponować formy wykształcone w kamiennej (lub tynkowanej) architekturze tego okresu na język ceglanego materiału. W tym ostatnim procesie uwidoczniły się wzory i przyzwyczajenia wykształcone w ciągu półwiecza dominacji neogotyku w sferze publicznej, czego dowodem jest stosowanie kształtek terakotowych czy wzorów układanych z wozówek. A zatem ceglane budowle $\mathrm{z}$ kręgu wczesnego modernizmu powstawały w wyniku nakładania się różnych, niekiedy przeciwstawnych tendencji. Z jednej strony wznoszono je z chęci czy raczej potrzeby stworzenia stylu, który wyrażałby „ducha czasu”, a więc odzwierciedlał modernizacyjny awans północnych Niemiec. $Z$ drugiej strony ów nowy styl miał wyrażać „ducha narodu” i regionalną specyfikę tego obszaru - przy czym chodziło o region historycznie, politycznie i ekonomicznie heterogeniczny, spojony dopiero granicami wilhelmińskiej Rzeszy.

Dodatkowym czynnikiem kierującym uwagę twórców w stronę budownictwa ceglanego było przywiązanie do wysokiej jakości rzemieślniczej dzieł sztuki, w tym także architektury, czego konsekwencją było m.in. unikanie stosowania

37 Obszerniej na temat domu Ossentów zob. Makała, Między prowincją a metropolia..., s. 318-319; Ines Wagemann, Der Architekt Bruno Möhring (1863-1929), Bonn 1992, s. 98-99, 269. 
tanich, zastępczych materiałów (np. gipsu do tworzenia detali architektonicznych naśladujących kamień). Równocześnie jednak moderniści niemieccy nie chcieli zrezygnować z możliwości seryjnego, przemysłowego wytwarzania elementów budowlanych, dlatego też byli zainteresowani technikami pozwalającymi na łatwą reprodukcję form, a więc i budownictwem ceglanym. Budowle ceglane o uproszczonych dekoracjach stawały się wyrazem nowych idei, nie tylko politycznych, lecz przede wszystkim artystycznych. Dzięki splotowi omówionych powyżej okoliczności architektura wczesnego modernizmu w północnych Niemczech stworzyła w ostatniej dekadzie przed wybuchem pierwszej wojny światowej interesującą formułę architektury ceglanej, posługującą się formami późnobarokowymi i klasycystycznymi. Tworzyła ona syntetyczny obraz przeszłości, opowiadanej nowoczesnym językiem formalnym - aluzji opartych raczej na skojarzeniach, a nie na dosłownych cytatach.

\section{Bibliografia}

Aber wir sind! Wir wollen! Und wir schaffen! Von der Großherzoglichen Kunstschule zur Bauhaus-Universität. 1860-2010, Bd. 1 (1860-1945), hrsg. Frank Simon-Ritz, Klaus-Jürgen Winkler, Gerd Zimmermann, Weimar 2010.

Andresen Hans-Günther, Bauen in Backstein. Schleswig-Holsteinische Heimatschutz-Architektur zwischen Tradition und Reform, Heide in Holstein 1989.

Barylewska-Szymańska Ewa, Gdańskie i lubeckie stowarzyszenia na rzecz ochrony zabytków w XIX i początkach XX wieku [w:] Studia z historii sztuki i kultury Gdańska i Europy Pótnocnej. Prace poświęcone pamięci Doktor Katarzyny Cieślak, red. Jacek Friedrich, Edmund Kizik, Gdańsk 2003, s. 401-402.

Baumhoff Anja, Bauhaus [w:] Deutsche Erinnerungsorte. Studien zur historischen Philosophie von Pierre Nora, red. Hagen Schulze, Etienne François, München 2001, s. 584-600.

Bracker Jürgen, Mythos und Nachleben der Hanse [w:] Die Hanse, Lebenswirklichkeit und Mythos, hrsg. C. Hirte, Hamburg 1989, s. 652-679.

Brix Michael, Nürnberg und Lübeck im 19. Jahrhundet, München 1981.

Bucciarelli Piergiacomo, Höger Fritz, Hanseatischer Baumeister 1877-1949, Berlin 1992.

Darenberg Thomas, Die Invalidensiedlung in Berlin-Frohnau (1937-1939) als Beispiel für eine militärische Wohnanlage in der Zeit des Nationalsozialismus [w:] Städtische und ländliche Siedlungsarchitektur zwischen 1900 und 1960 in Mecklenburg und Vorpommern sowie anderen Regionen, hrsg. Bernfried Lichtnau, Greifswald 1999, s. 283-298.

Droste Magdalena, Bauhaus 1919-1933. Reform und Avantgarde, Köln 2006.

Ebert Martin, Heinrich Tessenow. Architekt zwischen Tradition und Moderne, Weimar 2006.

Finke Manfred, Altstadt von Lübeck, Stadtdenkmal der Hansezeit, Kiel 2006.

Friedrich Jacek, Walka obrazów. Przedstawienia wobec idei w Wolnym Mieście Gdańsku. Gdańsk 2018.

Haiko Peter, Die Architektur des XX. Jahrhunderts. Zeitschrift für moderne Baukunst, Tübingen 1989. 
Rafat Hammer-Schenk Harold, Kunsttheorie und Kunstgeschichte des. 19. Jahrhunderts Makała in Deutschland, Stuttgart 1985.

Hutter Peter, Die feinste Barbarei. Das Völkerschlachtdenkmal bei Leipzig. Eine Studie über die „germanische“ Kunst des 19. Jahrhunderts, Mainz 1990.

Johnston Otto W., Der deutsche Nationalmythos. Ursprung eines politischen Programms, Stuttgart 1990.

Klinkott Manfred, Die Backsteinbaukunst der Berliner Schule von K.F. Schinkel bis zum Ausgang des Jahrhunderts, Berlin 1988.

Klinkott Manfred, Die Gestaltung von Backsteinfassaden unter dem Einfluss der politischen Verhältnisse in Preußen vor und nach 1871 [w:] Backsteinarchitektur in Mitteleuropa. Neue Forschungen. Protokollband des Greifswalder Kolloquiums 1998, hrsg. Ernst Badstübner, Uwe Albrecht, Berlin 2000, s. 321-343.

Kluckert Ehrenfried, Architektur des Barock in Deutschland, der Schweiz, Österreich und in Osteuropa [w:] Die Kunst des Barock. Architektur - Skulptur - Malerei, hrsg. Rolf Thoman, Köln 1997, s. 190-193.

Kokkelink Günther, Lemke-Kokkelink Monika, Baukunst in Norddeutschland. Architektur und Kunsthandwerk der Hannoverschen Schule 1850-1900, Hannover 1998.

Lange Ralf, Architektur in Hamburg, Hamburg 2008.

Maciakowska Zofia, Gdański konkurs architektoniczny z roku 1902 [w:] Kamienica w krajach Europy Północnej, red. Maria Sołtysik, Gdańsk 2004, s. 327-337.

Makała Rafał, Między prowincja a metropolia. Architektura Szczecina w latach 18911918, Szczecin 2011.

Makała Rafał, „Neorenesans pótnocny” jako niemiecki styl narodowy na przełomie XIX i XX w. [w:] Recepcja renesansu w XIX i XX wieku. Materiały Sesji Stowarzyszenia Historyków Sztuki, Łódź, listopad 2002, red. Małgorzata Wróblewska-Markiewicz, Łódź 2003, s. 307-314.

Muscheler Ursula, Das rote Bauhaus. Eine Geschichte von Hoffnung und Scheitern, Berlin 2016.

Müller Ulrike, Bauhaus-Frauen: Meisterinnen in Kunst, Handwerk und Design. Elisabeth Sandmann, München 2009.

Nipperdey Thomas, Deutsche Geschichte 1866-1918, Bd. 1, Arbeitswelt und Bürgergeist; Bd. 2, Machtstaat vor der Demokratie, München 1994.

Paarmann Michael, Historische Gutsanlagen in Schelswig-Holstein. Ein ausgeschlagenes Erbe oder Chance für die Zukunft [w:] Schlösser und Herrenhäuser der Ostseeregion. Bausteine einer europäischen Kulturlandschaft, hrsg. Kilian Heck, Sabine Bock, Jana Olschewski, Schwerin 2017, s. 387-400.

Posener Julius, Berlin auf dem Wege zu einer neuen Architektur. Das Zeitalter Wilhelms II, München 1979.

Reform der Großstadtkultur - das Lebenswerk Fritz Schumachers (1869-1947). Dokumentation zur gleichnamigen Ausstellung 2013 im Kunsthaus Hamburg, hrsg. Dieter Schädel, Jörg Beleites, Hamburg 2013.

Schneider Romana, Vittorio Magnago Lampugnani: Architektur in Deutschland 19001950, Stuttgart 1994.

Schumacher Fritz, Grundlagen der Baukunst, München 1916.

Siebenbrodt Michael, Schöbe Lutz, Bauhaus 1919-1933, New York 2009. 
Störtkuhl Beate, Liegnitz - die andere Moderne. Architektur der 1920er Jahre, München 2007 (Schriften des Bundesinstituts für Kultur und Geschichte der Deutschen im östlichen Europa, Bd. 32).

Turtenwald-Quiring Claudia, Fritz Höger (1877-1949). Architekt zwischen Stein und Stahl, Glas und Beton, https://www.researchgate.net/publication/35419479_Fritz_ Hoger_1877-1949_Architektur_zwischen_Stein_und_Stahl_Glas_und_Beton [dostęp: 12.06.2018].

Wagemann Ines, Der Architekt Bruno Möhring (1863-1929), Bonn 1992.

\section{References to the Modern Tradition in the Early Modernist Brick Architecture of Northern Germany}

One of the manifestations of the so called 'conservative modernism' was the reference to the brick building tradition in Northern Germany. The trend was primarily associated with the activities of Fritz Schumacher and Fritz Höger in Hamburg and Bremen in the 1920s and 1930s, but the genesis of this architecture dates back to the first decade of the $20^{\text {th }}$ century and is associated with the attempts to shape North German patriotism. Just as in the art of neo-Gothic, brick architecture of 'conservative modernism' was meant to express the 'North German Identity', and in fact help in the creation of identities of the Bismarck Germany. Like the late neo-Gothic architecture, this architecture was perceived as a kind of 'Hanseatic style', reflecting the specificity (perceived in a mythologized way) of the Hanseatic League as a prefiguration of the New Germany and their power in maritime trade. Early-modern architecture continued to refer to the art of the past. However, the way of referring to the past changed: with only few quotes from the old art, with a considerable simplification of historical styles' and so did the historical point of reference. In addition, the modernists became more interested in the brick building of the $17^{\text {th }}$ and $18^{\text {th }}$ centuries, the times of the Baroque and early Neoclassicism. This is evident in the works of the most important architects of North German modernism, including Fritz Höger, Fritz Schumacher, or Bruno Möhring but also works of lesser-known, though certainly interesting artists like Johann Garleff, Erich Blunck or Eugen Prinz. The interest of the North German architects of early modernism in brick construction is an element of a wider process that had been thriving in Northern Germany since the early 1900s. Interestingly enough, this process was equally intense in great artistic centres (Hamburg and Bremen) as well as in less-significant cities which were looking for their identity or tried to recreate it, as was the case in Kiel, Lubec or Szczecin. This paper is an attempt to show the evolution of this architecture and its most important features. The examples have been selected to show the most important characteristics of this architecture and its geographical range. 